\title{
Taxation and distribution of income in Brazil: new evidence from personal income tax data
}

\author{
Tributação e distribuição de renda no Brasil: \\ novas evidências a partir de dados da DIRPF
}

SÉRGIO WULFF GOBETTI

RODRIGO OCTÁVIO ORAIR*

RESUMO: Este texto faz uma análise crítica da tributação da renda e do lucro no Brasil, mostrando como medidas adotadas nas décadas de 1980 e 1990, por recomendação do mainstream, restringiram o papel redistributivo do imposto de renda. Analisando dados tributários, verifica-se elevado grau de concentração de renda no topo da distribuição, baixa progressividade e violação dos princípios da equidade horizontal e vertical. A principal razão destas distorções é a isenção integral dos dividendos a acionistas, privilégio atípico nos países desenvolvidos. Propõe-se recuperar uma agenda de reforma tributária focada na progressividade, tema que voltou ao debate com Piketty (2014).

PALAVRAS-CHAVE: Imposto de renda; Progressividade; Reforma tributária

ABSTRACT: able This paper presents a critical analysis of income and profit taxes in Brazil, arguing that measures adopted in the 1980s and 1990s, as a result of mainstream recommendations, hindered the redistributive role of taxes. An examination of tax data reveals a high degree of top income concentration, low tax progressivity and violations of the principles of horizontal and vertical equity. The main reason for these distortions is the complete tax exemption of dividends, a benefit that is very rarely seen in developed countries. We propose a return to a progressivity-focused tax reform plan, a theme that has returned as a focus of debates with Piketty (2014).

KEYWORDS: Income tax; Tax progressivity; Tax reform; Income distribution; Tax data. JEL Classification: H24; N46; E62.

\footnotetext{
* Técnico de Planejamento e Pesquisa do IPEA. Correio eletrônico: swgobetti@gmail.com; Técnico de Planejamento e Pesquisa do IPEA e pesquisador associado ao International Policy Centre for Inclusive Growth (IPC-IG). Correio eletrônico: rodrigo.orair@ipea.gov.br. Submitted 28/September/2015; Approved: $17 / \mathrm{March} / 2016$.
} 


\section{INTRODUCTION}

Brazil's tax burden is one of the highest among developing countries - around 33 per cent of Gross Domestic Product (GDP) - which is close to the average of the countries comprising the Organisation for Economic Co-operation and Development (OECD). Unlike developed economies, however, the Brazilian burden is more concentrated on indirect and regressive taxes, as opposed to direct and progressive ones.

The country is also one of the only cases where dividends paid by corporations to their shareholders are completely tax-free. This personal income tax (PIT) exemption was introduced in 1995, together with another benefit that significantly reduced corporate income tax (CIT): the possibility of deducting a fictitious expense termed 'interest on net equity' from their taxable profit.

These two fiscal peculiarities, as will be shown, are partially responsible for the low taxation of profits as well as the low progressivity of the country's PIT. However, they are not a consequence of the unbridled creativity of tax authorities but, rather, have their roots in popular concepts and economic policy prescriptions of the 1980s to 1990 s, and which began to be questioned in the realm of mainstream economic theory by recent literature, from which Piketty (2014) draws.

This literature is a result of a methodological and historical evolution of the theory of optimal taxation that, originally, based on the alleged equity-efficiency trade-off and rather restrictive hypotheses regarding individual behaviour and economic dynamics, produced extreme models in which income tax should have a linear rate and capital income should not be taxed so as not to distort economic incentives. ${ }^{1}$

Influenced by narrow interpretations of the optimal taxation literature, in a scenario where the neoclassical economic revolution of the 1970s questioned Keynesian fiscal policy, a sort of mainstream consensus was built among policymakers that tax policy, so as not to introduce distortions in the economic system, should abstain from any distributive aspirations, shifting this classic function of fiscal policy to public expenditure instead. ${ }^{2}$

This was the fiscal policy model that prevailed - and still prevails - in Brazil,

\footnotetext{
${ }^{1}$ Such were the conclusions of the articles from Mirrlees (1971) and Atkinson-Stiglitz (1976), respectively. Although, over time, both authors have since reviewed their stances and adopted a more realistic and pragmatic approach (see Banks and Diamond, 2010; Mirrlees et al., 2011). Comprising the recent literature that questions the design of the optimal taxation model are both the new generation represented by Thomas Piketty and Emmanuel Saez, among many others - and revisions by the older generation - represented by James Mirrlees, Peter Diamond, Anthony Atkinson and Joseph Stiglitz.

${ }^{2}$ The testimony of Andrea Lembruger Viol (2005, p. 12), an economist of the Brazilian Federal Revenue Secretariat, illustrates the point: "Recently it has been recommended, especially in developing countries where income distribution is very concentrated, that taxation should be kept neutral and expenditure should be dedicated to redistribution. Many countries have adjusted their taxation systems in light of this recommendation."
} 
and which must be re-evaluated in the face of tell-tale signs of breakdown in redistributive expenditure and barriers to its financing. History shows that paradigms are revised in moments of crisis, such as today. The existence of PIT as an instrument of progressive taxation in developed countries points to that fact. Up until the 20th century, maximum rates did not exceed 10 per cent, due to resistance from local elites. Political and economic threats, in the context of the First World War and the Russian revolution, were necessary for these elites to agree to sharply raise tax rates to levels above 50 per cent.

In England and the USA, maximum PIT rates exceeded 90 per cent in the 1940s and remained at that level for a few decades. It is interesting to note how the 'confiscatory' experience of the period deeply affected the local elites, helping to understand the roots of the conservative revolution of the 1980s, in particular proposals for tax cuts for the wealthiest in both countries, grounded on supply-side theories such as the Laffer curve, according to which tax rate increases after a certain point would lead to a decrease in revenue by discouraging labour and investment.

Convinced that the progressivity of the tax system needed to be eliminated because it penalised capable entrepreneurs and obstructed economic prosperity, Ronald Reagan promoted two tax reforms. The first, more moderate one, in 1981, reduced the top PIT rate from 70 per cent to 50 per cent. The second, more radical one, was introduced in 1986-1988, reducing the number of income brackets from 16 to four, eliminating the tax exemption range, increasing the minimum rate from 11 per cent to 15 per cent and reducing the top rate to 28 per cent. Furthermore, an intermediary income bracket was created immediately beneath the top, subject to a 33 per cent rate, thus softening the progressive tax ladder.

Curiously, the configuration that has characterised Brazilian PIT in the early 1990s - three tax brackets, with a 27.5 per cent top rate, after four decades of 12 brackets and top rates of at least 50 per cent - is very similar to the Reagan model, which had reducing progressivity as an explicit objective. In addition, during the Reagan administration, CIT was reduced. In a similar vein, two decades later, in 2003 during George W. Bush's administration, tax on dividends was lowered to 15 per cent at the federal level.

This reorientation of taxation in favour of capital owners and the richest, with a reduction in degrees of progressivity, according to Piketty, Saez and Zucman (2013), has been repeated in varying degrees in practically every developed country between 1980 and 2010 and partly explains the increase in inequality during the period. However, it is interesting to point out that not even Reagan and Bush were able to do what the Brazilian government did in 1995, by completely exempting dividends. Moreover, while in the USA the conservative advance has been partially reversed during recent administrations, as Barack Obama increased dividend tax and other taxes for the richest again in 2013, in Brazil there have been no progressive tax reforms over the last 30 years of democratic rule, 12 of which under a centre-left government. 


\section{THE EVOLUTION OF INCOME TAXATION IN BRAZIL}

The institution of progressive taxes on income has played a decisive role in the development of the welfare state and the transformation of the structure of inequality in the $20^{\text {th }}$ century, as evidenced by Piketty (2014). In Brazil there is no similar long-term and detail-rich study which would allow for the analysis of the evolution of tax structure and how it relates to welfare state.

In any case, PIT has historically evolved in a coherent form according to international tendencies. Since the early days of the Brazilian republic, the idea of its creation following European moulds was repeatedly championed by such personalities as Rui Barbosa, the first Minister of Finance of the republican regime, as a mechanism to reduce government deficits and, at the same time, inequalities in general. However, it was only in 1922 that the proposal was finally accepted and approved by a majority of Congress.

As in Europe and the USA, Brazilian PIT had moderate rates at first, topping out at 8 per cent but with a broad base of capital and labour incomes. The top rate was gradually increased, reaching 20 per cent in 1944 and jumping to 50 per cent in 1948, after the end of the Second World War. There it remained until 1961, when then president Jânio Quadros increased it to 60 per cent, and, soon afterwards, his successor João Goulart increased it again to 65 per cent, the highest percentage in Brazilian history, right before the 1964 military coup. One of the first measures of the authoritarian regime that immediately followed was a return to the 50 per cent top rate, while in the USA this top rate was reduced from 90 per cent to 70 per cent. Despite this, the PIT structure was still very progressive, not only because of its top rate but due to the existence of 12 tax brackets, and impacting a broad spectrum of capital and labour incomes. Although the system allowed for a broader range of deductions, which restricted this progressivity.

This situation endured until 1988-1989, when then president José Sarney, in a Reagan-like move, abruptly reduced the number of tax brackets from 11 to only three, and the top rate from 50 per cent to 25 per cent. From then on - despite the new democratic Constitution established on the basis of the desire to develop a robust Brazilian welfare state acknowledging a series of social demands that had been neglected during the military dictatorship - PIT would never return to its previous progressive structure. On the contrary, as the country was building its social protection network through expenditure, it shied away from the redistributive goals of taxation policy in line with mainstream economic prescriptions, although empirical evidence supporting such a theory is fragile as shown in Banks and Diamond (2010), Diamond and Saez (2011) and Piketty, Saez and Zucman (2013). The cycle of increasing tax benefits for capital owners and for the richest was completed in the 1990s, with the advent of tax-free dividends and the consolidation of a tax structure featuring low progressivity, which will be explained further.

It is important to observe that in the classical tax system, corporate profits are taxed after balancing of accounts, and dividends paid to shareholders are taxed a 
second time over. This two-stage taxation - both at personal as well as corporate levels - was the tax model that prevailed worldwide throughout the $20^{\text {th }}$ century, as well as in Brazil for most of it. However, by the 1990s the country no longer followed a purely classical system, because dividends no longer figured at the tax base for PIT, as in many countries, but were, rather, subject to withhold tax, at lower rates than payroll taxes, which were subject to the progressive table.

Therefore, the tax regime already offered special treatment to dividend recipients, ameliorating the effects of double taxation. However, in 1995, the Brazilian government went a step further and, under the guise of attracting capital and fostering investment, proposed two important legislative changes in the taxation through Law 9,249/95:

"Art. 9. The legal entity can deduct, for purposes of calculating actual profits, interests paid or individually credited to the owner, partners or shareholders, as remuneration of equity, calculated over net equity and limited to the variation, pro rata diem, of the Long-Term Interest Rate.

$[\ldots]$

Art. 10. Profits or dividends calculated based on results starting from the month of January 1996, paid or credited by legal entities and taxed based on actual, presumed or arbitrated profit, will not be subject to taxation at the source, nor will they compose the recipient's tax base, be it a legal entity or natural person, residing in the Country or abroad."

Article 9 instituted the figure of 'interest on net equity' (juros sobre capital próprio - JSCP), a fictitious expense which a company might deduct from its tax base so as to equate itself with another indebted company that, in this case, deduct the costs with interests from their profits. The fictitious expense is calculated by applying the long-term interest rate over the company's equity, and this 'interest' is paid to shareholders as a type of dividend. The practical effect is that a portion of the profits, which would be taxed at the 34 per cent rate, considering both the corporate income tax (imposto de renda das pessoas jurídicas - IRPJ) and the social contribution over net profit (contribuição social sobre o lucro líquido-CSLL), is then only taxed at a 15 per cent rate when paid to shareholders. Article 10 states that dividends, previously taxed at the same 15 per cent rate as other capital gains, would be completely tax-free.

Taxation was reduced by both channels, and its effect on shareholder participation of profits is exemplified in Table 1 . Before the change, corporate profits were taxed at 34 per cent. Once disbursed, the 66 per cent share of dividends were taxed at a 15 per cent withholding tax rate at the personal level, which reduced the effective amount received by shareholders to 56.1 per cent, and the remaining 43.9 per cent was retained by the government in the form of taxes.

After the changes, the same corporation became able to deduct the JSCP from profits to arrive at the tax base. Hypothetically, let us suppose that this is a 30 per cent 
share. The tax base falls to 70 per cent, and corporate tax falls to 23.8 per cent, which is partially compensated by the 15 per cent tax over the JCSP, or 4.5 per cent of gross profits. This results in a tax decrease, from 34 per cent to 28.3 per cent. In addition, dividend exemption reduces taxes on this share from 9.9 per cent to zero. As a consequence, shareholders who previously received 56.1 per cent of the profit went on to receive 71.7 per cent, with the remaining 28.3 per cent going to the government.

Table 1: Profit and dividend taxation in Brazil

\begin{tabular}{l|cc|c}
\hline \multicolumn{1}{c|}{ Profit, dividends and taxes } & Before Lei No. 9.249 & After Lei No. 9.249 & Difference \\
\hline Gross profit & 100 & 100 & 0 \\
Taxable profit & 100 & 70 & -30 \\
$\quad$ IRPJ (25\%) & 25 & 17.5 & -7.5 \\
CSLL (9\%) & 9 & 6.3 & -2.7 \\
JSCP & 0 & 30 & 30 \\
$\quad$ Withholding tax (15\%) & 0 & 4.5 & 4.5 \\
Dividends & 66 & 46.2 & -19.8 \\
$\quad$ Withholding tax (15\%-0\%) & 9.9 & 0 & -9.9 \\
Tax total & 43.9 & 28.3 & -15.6 \\
Shareholder participation & 56.1 & 71.7 & 15.6 \\
\hline
\end{tabular}

Source: Authors' elaboration.

Values might change according to the amount of JCSP and dividends disbursed by corporations to their shareholders. As a rule, the higher the amount deducted for JSCP, the larger the benefit to shareholders. If the amount deducted for JSCP were increased to 50 per cent, for instance, final taxation would fall to 24.5 per cent, and shareholder gains would increase to 75.5 per cent. In contrast, if the company did not perform JSCP deductions, the only benefit would be dividend exemption, and final taxation would reach 34 per cent.

This is the situation that prevails among large corporations. For medium and small corporations, whose tax calculation is simplified, the levels of taxation on profits are even lower, reaching at most 10.88 per cent of revenue. In the service sector such tax systems, together with the complete exemption of disbursed dividends, provide incentives for distortive effects such as subcontracting, outsourcing and pejotização (i.e., shifting from a natural person to a legal entity) for purposes of tax avoidance. ${ }^{3}$

\footnotetext{
${ }^{3}$ In the presumed system, common among medium-sized corporations, the legislation presumes that profits are equal to, depending on economic sector, up to 32 per cent of revenue. The IRPJ and CSLL are calculated over the presumed base, which results in a 10.88 per cent maximum tax rate over revenue. In the service sector, total taxation on companies varies from 16.33 per cent to 19.53 per cent of revenue if the corporate is framed under presumed system, or from 4.5 per cent to 16.85 per cent if it is framed under the Simple system for small corporates. This encourages an individual person to constitute a legal
} 
In this context, economic or legal arguments seeking to defend such a situation - mainly tax-free dividends, under the pretext of avoiding the 'double taxation of profits' - are often grounded in formalities and end up contributing to the perpetration of economic distortions and enormous fiscal injustice.

From a legal standpoint, the concept of 'double taxation' is questionable because the passive subjects of the CIT and the PIT over dividends are different. ${ }^{4}$ From an economic standpoint, the argument is formal because it is of no interest to shareholders how many times profit is taxed but, rather, only the final result of taxation. If we were to increase CIT from 34 per cent to 44 per cent, we would achieve approximately the same result as ending dividend exemption, and would not engage in 'double taxation'. However, this alteration would be worse for the corporation, by treating retained (and reinvested) profit and distributed profit to shareholders (which will become mostly private savings and not necessarily return to the corporation) the same way.

In addition, empirical literature lacks conclusive results that demonstrate that tax benefits to capital ownership (dividend exemption and JSCP deduction) have led to an increase in investment. On the contrary, investments stagnated for over a decade after the adoption of these measures. However, one could unequivocally state that they have consolidated the under-taxation of profits in the country and contributed to the low progressivity in PIT, as will be demonstrated further.

\section{TAXATION OF PROFITS AND DIVIDENDS IN THE DEVELOPED WORLD}

The classical tax system, as previously mentioned, foresees profit tax at the corporate level and, subsequently, if dividends are disbursed to shareholders, they are taxed at the personal level. Among the 34 OECD countries, which include developed and some developing economies that embrace the principles of representative democracy and free market economy, only Estonia, Mexico, Greece and Slovakia have strayed from this model by only taxing profit once. In 2011, however, Slovakia introduced a social contribution to finance health care, while Mexico went back to taxing dividends in 2014 as Greece in 2009. Only Estonia was left with tax-free dividends as in Brazil..$^{5}$

entity providing a service in order not to be taxed up to 27.5 per cent. See Castro (2014) and Afonso (2014) for further details.

${ }^{4}$ See Freitas, Costa and Moreira (2012) for more on this subject.

${ }^{5}$ Greece taxes dividends at 10 per cent, and Mexico also taxes them at source at 10 per cent, and at an additional 7.14 per cent for those with an annual income of over MXN3 million (or BRL600,000). Estonia is a small country which, in the early 1990s, after the end of Soviet rule, implemented one of the most radical pro-market reforms in the world. Its tax system, for instance, was a pioneer by introducing, in 1994, a uniform tax rate (20 per cent) and a tax-free dividends. The result is that Estonia has become one of the most liberal and unequal economies in the European Union. 
The remaining OECD countries, despite adopting mechanisms to integrate CIT and PIT and partially exempt dividends, practise double taxation. Some have higher taxes at personal level, while some tax more corporates, but what is important is that, on average, profits absorbed by the State as levies are higher than in Brazil. Table 2 shows that, on average, profit and dividend taxation in OECD countries is of 43.1 per cent (or 47.9 per cent weighted by GDPs), according to 2015 rates. This tax burden varies from 20 per cent in Estonia to 64.4 per cent in France.

Table 2: Tax rates on profits and dividends in OECD countries (2015)

\begin{tabular}{|c|c|c|c|c|c|c|c|c|c|}
\hline \multirow[b]{2}{*}{ Country } & \multicolumn{4}{|c|}{ Corporate } & \multicolumn{4}{|c|}{ Personal } & \multirow[b]{2}{*}{$\begin{array}{l}\text { Total tax } \\
(B+C) / A\end{array}$} \\
\hline & $\begin{array}{l}\text { Pre-tax } \\
\text { profit (A) }\end{array}$ & $\operatorname{Tax}(B)$ & $\operatorname{Tax}(\%)$ & $\begin{array}{l}\text { Distributed } \\
\text { profit }\end{array}$ & $\begin{array}{l}\text { Withholding } \\
\operatorname{tax}(\%)\end{array}$ & $\begin{array}{c}\text { Tax over } \\
\text { extrapolated } \\
\text { dividends (\%) }\end{array}$ & $\begin{array}{l}\text { Imputation } \\
\text { credit }\end{array}$ & $\begin{array}{l}\text { Tax } \\
\text { (C) }\end{array}$ & \\
\hline Australia & 142.9 & 42.9 & 30 & 100 & .. & 49 & 42.9 & 27.1 & 49 \\
\hline Austria & 133.3 & 33.3 & 25 & 100 & 25 & 25 & .. & 25 & 43.8 \\
\hline Belgium & 151.5 & 51.5 & 34 & 100 & .. & 25 & .. & 25 & 50.5 \\
\hline Canada & 135.7 & 35.7 & 26.3 & 100 & .. & 49.5 & 34.5 & 33.8 & 51.2 \\
\hline Chile & 129 & 29 & 22.5 & 100 & .. & 40 & 29 & 22.6 & 40 \\
\hline Czech Rep. & 123.5 & 23.5 & 19 & 100 & 15 & 15 & .. & 15 & 31.2 \\
\hline Denmark & 130.7 & 30.7 & 23.5 & 100 & .. & 42 & .. & 42 & 55.6 \\
\hline Estonia & 125 & 25 & 20 & 100 & .. & 0 & .. & 0 & 20 \\
\hline Finland & 125 & 25 & 20 & 100 & .. & 33 & .. & 28.1 & 42.4 \\
\hline France & 157.2 & 57.2 & 36.4 & 100 & .. & 44 & .. & 44 & 64.4 \\
\hline Germany & 143.2 & 43.2 & 30.2 & 100 & 26.4 & 26.4 & .. & 26.4 & 48.6 \\
\hline Greece & 135.1 & 35.1 & 26 & 100 & 10 & 10 & .. & 10 & 33.4 \\
\hline Hungary & 123.5 & 23.5 & 19 & 100 & .. & 16 & .. & 16 & 32 \\
\hline Iceland & 125 & 25 & 20 & 100 & .. & 20 & .. & 20 & 36 \\
\hline Ireland & 114.3 & 14.3 & 12.5 & 100 & .. & 51 & .. & 51 & 57.1 \\
\hline Israel & 136.1 & 36.1 & 26.5 & 100 & .. & 30 & .. & 30 & 48.6 \\
\hline Italy & 137.9 & 37.9 & 27.5 & 100 & 26 & 26 & .. & 26 & 46.4 \\
\hline Japan & 147.3 & 47.3 & 32.1 & 100 & 20.3 & 20.3 & .. & 20.3 & 45.9 \\
\hline Luxembourg & 141.3 & 41.3 & 29.2 & 100 & .. & 40 & .. & 20 & 43.4 \\
\hline Mexico & 142.9 & 42.9 & 30 & 100 & 10 & 42 & 42.9 & 17.1 & 42 \\
\hline Netherlands & 133.3 & 33.3 & 25 & 100 & .. & 25 & .. & 25 & 43.8 \\
\hline New Zealand & 138.9 & 38.9 & 28 & 100 & .. & 33 & 38.9 & 6.9 & 33 \\
\hline Norway & 137 & 37 & 27 & 100 & .. & 27 &.. & 27 & 46.7 \\
\hline Poland & 123.5 & 23.5 & 19 & 100 & 19 & 19 & .. & 19 & 34.4 \\
\hline Portugal & 146 & 46 & 31.5 & 100 & 25 & 28 & .. & 28 & 50.7 \\
\hline Slovakia & 128.2 & 28.2 & 22 & 100 & .. & 0 & .. & 0 & 22 \\
\hline Slovenia & 120.5 & 20.5 & 17 & 100 & 25 & 25 & .. & 25 & 37.8 \\
\hline South Korea & 131.9 & 31.9 & 24.2 & 100 & .. & 41.8 & 11 & 35.4 & 51 \\
\hline Spain & 138.9 & 38.9 & 28 & 100 & .. & 24 & .. & 24 & 45.3 \\
\hline Sweden & 128.2 & 28.2 & 22 & 100 & .. & 30 & .. & 30 & 45.4 \\
\hline Switzerland & 126.8 & 26.8 & 21.2 & 100 & .. & 21.1 & .. & 21.1 & 37.8 \\
\hline Turkey & 125 & 25 & 20 & 100 & .. & 35 & .. & 17.5 & 34 \\
\hline UK & 126.6 & 26.6 & 21 & 100 & .. & 37.5 & 11.1 & 30.6 & 45.1 \\
\hline USA & 164.3 & 64.3 & 39.1 & 100 & .. & 30.3 & .. & 30.3 & 57.6 \\
\hline
\end{tabular}

Source: OCDE Tax Database (Table II.4, extracted 29 June 2015).

To understand Table 2, it is worth pointing out that, despite maximum PIT rates being over 50 per cent in some countries, taxation on dividends is lower thanks to imputation credits or by the incidence of smaller rates (withholding taxes, for instance). In any case, excluding Estonia, taxation of dividends at the personal level varies from 6.9 per cent (New Zealand) to 35.4 per cent (South Korea), averaging 24.1 per cent.

Another important matter is that, in historical terms, these are among the lowest average tax rates on profits and dividends over the last 35 years. In 1981, according 
to OECD data, average taxation on profits, both personal and corporate, reached 75.2 per cent. In other words, developed countries have already significantly reduced the taxation but still present superior levels when compared with Brazil. In the next section the effect that such tax characteristics have on PIT progressivity will be explored.

\section{HOW PROGRESSIVE ARE PERSONAL INCOME TAXES IN BRAZIL?}

This section rates progressivity of the PIT according to the most recent data from the 'Large Numbers of Personal Income Tax Declarations' (Grandes Números das Declarações de Imposto de Renda das Pessoas Físicas - DIRPF), systematised in Tables 3 to $5 .^{6}$ The initiative to increase transparency by releasing more detailed information to the public has been enabling more realistic analyses of the top of the income distribution and tax progressivity in Brazil. ${ }^{7}$

Based on these numbers, it can be observed that the volume of dividends has nearly doubled in actual values, from BRL149 billion in 2007 to BRL287 billion in 2013, an increase 41 per cent higher than that of GDP. These values benefit 2.1 million people, or 7.9 per cent of taxpayers, with a higher participation in the top strata of the income distribution, where they represent 82 per cent of taxpayers with income above BRL1.3 million. Another interesting fact is that the largest portion of this group's income is exempt - two thirds of the total on average - especially at higher brackets. In other words, there are asymmetries in the distribution of those receiving dividends, who are more concentrated at the top and whose major portion of income is exempt from taxes.

Table 3: DIRPF incomes (2007-2013) - in constant BRL billions, base year 2013

\begin{tabular}{lccccccc}
\hline \multicolumn{1}{c}{ Incomes } & $\mathbf{2 0 0 7}$ & $\mathbf{2 0 0 8}$ & $\mathbf{2 0 0 9}$ & $\mathbf{2 0 1 0}$ & $\mathbf{2 0 1 1}$ & $\mathbf{2 0 1 2}$ & $\mathbf{2 0 1 3}$ \\
\hline Taxable & 968.5 & $1,034.60$ & $1,071.20$ & $1,125.20$ & $1,197.70$ & $1,271.00$ & $1,293.20$ \\
\hline Subject to withholding tax & 107.6 & 149.8 & 139.3 & 163.6 & 204.9 & 192.7 & 207.4 \\
Labour incomes & 30.1 & 50.6 & 55.1 & 63.5 & 70.1 & 74.6 & 97.6 \\
Fixed income investments & 32.3 & 45.8 & 42.5 & 45.6 & 57.2 & 52.8 & 45.2 \\
Other capital ownership incomes & 45.3 & 53.3 & 41.7 & 54.5 & 77.6 & 65.2 & 64.6 \\
\hline Exempt & 293.2 & 477.6 & 473.3 & 530.4 & 583 & 601.5 & 632.2 \\
Labour incomes & 47.2 & 89.2 & 92.1 & 94.8 & 97.5 & 105.8 & 113.5 \\
Profits and dividends & 149.4 & 196.9 & 195.8 & 229.7 & 257 & 271.4 & 287.3 \\
Other capital ownership incomes & 65 & 128.2 & 127.3 & 145.8 & 167.8 & 166.5 & 171.9 \\
Asset transfers & 31.7 & 63.3 & 58.2 & 60.3 & 60.6 & 57.9 & 59.4 \\
\hline \multicolumn{1}{c}{ Total } & $1,369.40$ & $1,661.90$ & $1,683.80$ & $1,819.20$ & $1,985.50$ & $2,065.20$ & $2,132.70$ \\
\hline
\end{tabular}

Source: Authors' elaboration based on DIRPF data. Note: Values converted by the IPCA annual arithmetic average.

\footnotetext{
${ }^{6}$ The tabulations and results of this section demanded a series of estimation procedures that are described in a supplementary methodological appendix, available with the full digital version of this article.

${ }^{7}$ For example, Castro (2014), Afonso (2014), Medeiros and Souza (2014), Medeiros, Souza and Castro (2015) and Gobetti and Orair (2015) make use of tax data. Among the studies that analyse tax progressivity based on household surveys, it is worth mentioning Rocha (2002), Hoffmann (2002), Receita Federal (2004), Silveira (2008), Soares et al. (2010) and Hanni, Martner and Podestá (2015).
} 
For a better understanding of the data, it must be made clear that the three aggregate incomes in Tables 3 to 5 are composed of dozens of heterogeneous components. Although each aggregate mixes incomes from labour and capital ownership, there is a predominance of labour incomes among the taxable, and capital incomes among the other two (subject to withholding taxes and exempt). The components can then be regrouped, by approximation to their main origins, between labour and capital, in addition to asset transfers that are not an income flow.

This grouping also reveals tax conditions that are more favourable to capital incomes. Progressive taxation falls on taxable income, in addition to around half of those subject to withholding taxes, both directly linked to labour. There are four rates for incremental brackets at the tax base, from 7.5 per cent to 27.5 per cent based on certain exemption limits. For that reason, the average effective rates are far lower: starting from close to zero up to 20.8 per cent at the last bracket (see Table 5). These are relatively low rates, when compared to OECD countries or even Latin American ones - which already restrict PIT progressivity, as shown by Castro (2014).

However, the main limitations regarding progressivity are related to the taxation of capital incomes. A little over half of income subject to withholding taxation derives from capital ownership and will be taxed according to linear (neutral) rates. The averages for these rates, across all income brackets in Table 5, will be similar and inferior to those of taxable income. Except in the first brackets predominantly featuring labour income under progressive taxation. In addition, the bulk of capital ownership incomes will be tax-free, especially dividends.

In Table 4, it is possible to identify a direct relationship according to which the weight of tax-free income and those subject to withholding tax increases as higher income brackets are reached, be it among recipients of dividends or not. Such a relationship reflects the concentrated profile of capital income and, together with the legal framework awarding them tax advantages, ends up leading to a paradox: effective rates decrease at the top of the income distribution.

The average rates for total income, in the second-to-last column of Table 5, grow up to 11.8 per cent in the intermediary stratum of the 1.5 million taxpayers who earn between BRL162,700 and BRL325,400, where the main source of income is still taxable (wages). From that point on, there is an inflexion in the rates, which fall to 6.7 per cent due to the predominance of capital incomes (tax-free or taxed at linear lower rates).

It is worth pointing out that the estimations are averages that cloud the heterogeneity among income brackets and population groups. For example, the average tax rates for recipients of profits and dividends, a category which gathers 60 per cent of exemptions, were up to 6.6 per cent - far inferior to the 14.1 per cent borne by nonrecipients in equivalent income brackets (between BRL162,700 and BRL325,400).

Such findings lead us to call into question the equity of the Brazilian PIT, considering the different types of income and the tax treatment they receive. The principles of horizontal and vertical equity, when using grouped income data, might be translated into the need for the average tax rate to be equal (or neutral) among taxpayers groups with the same income levels and increasing (or progressive) for 


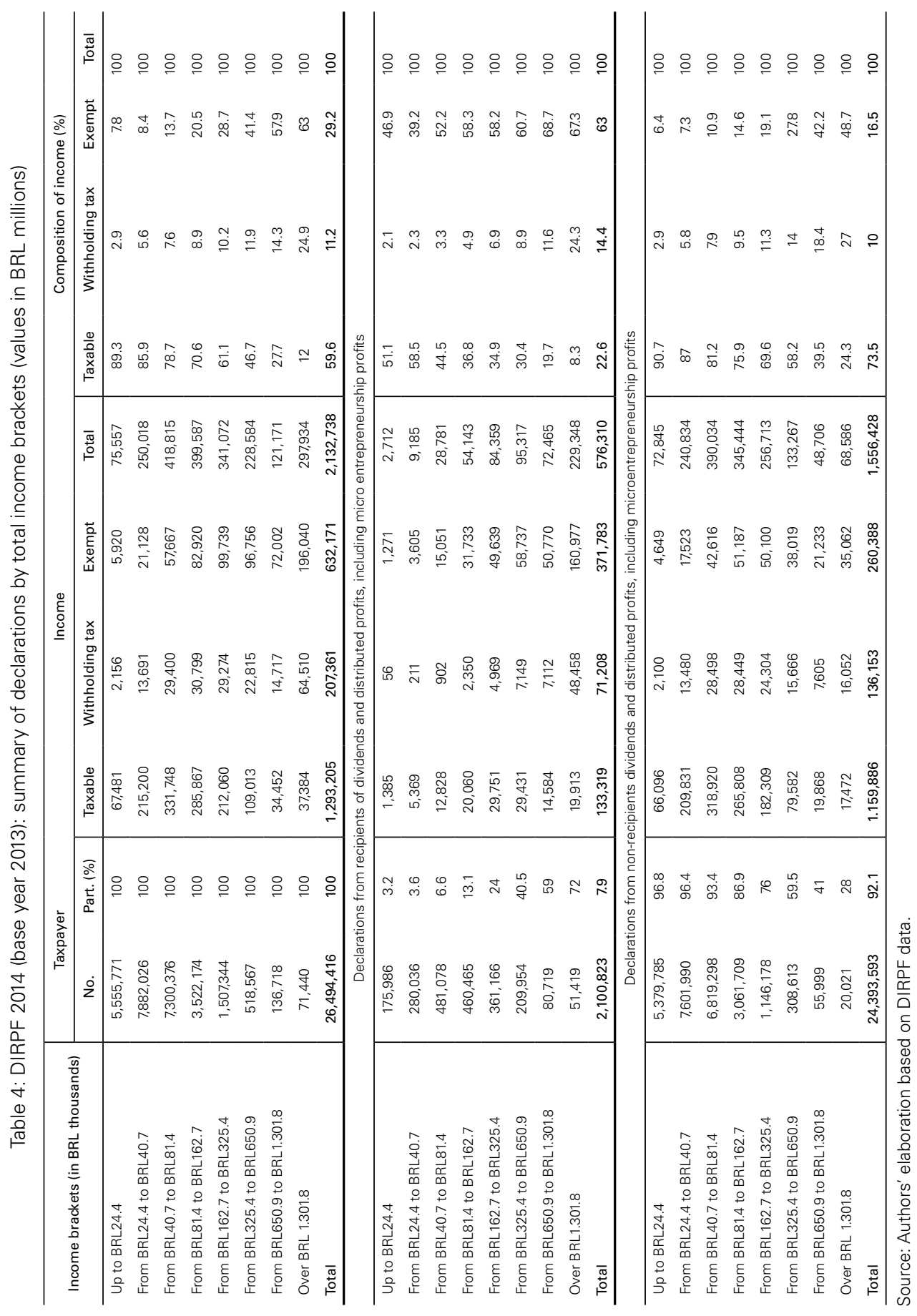




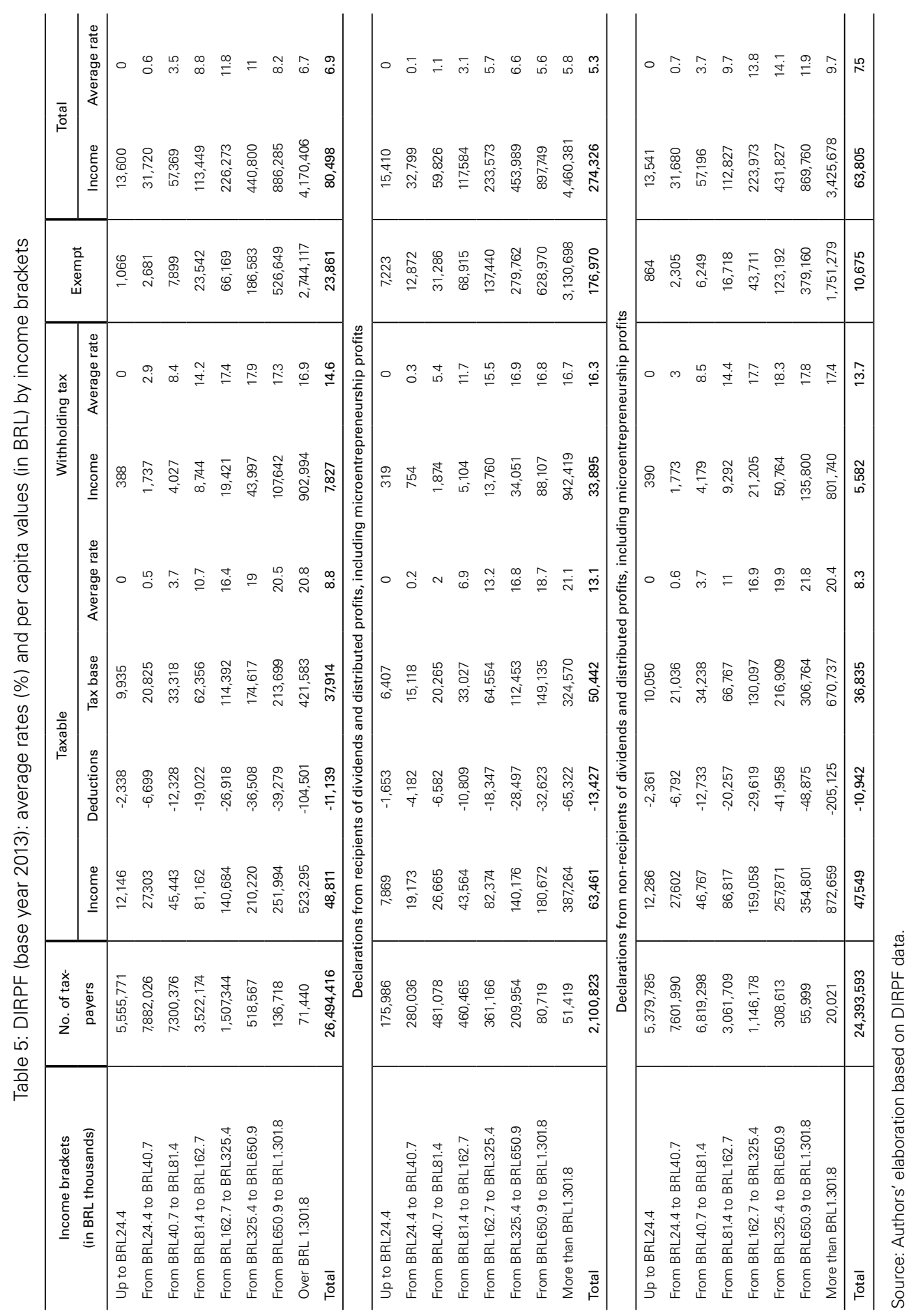


higher incomes groups. These results suggest that both principles are violated under the current structure of the PIT. From a horizontal standpoint, because recipients of dividends have lower average rates, and from a vertical perspective, as rates decrease at the top of the distribution.

Aiming to provide a broad perspective on the redistributive impacts of PIT, data relative to the top of the income distribution were supplemented by those of the bottom, resulting from household survey with a procedure to adjust for the bias that underestimate such incomes with additional informations from tax data and national accounts. ${ }^{8}$ Results are laid out in Table 6 and show that the PIT has a clear, albeit limited, redistributive impact, broadening participation in earnings of 95 per cent of the population to the detriment of the richest. It is estimated that PIT leads to a reduction in the Gini index, from 0.647 to 0.632 , representing a 2.3 per cent decrease. ${ }^{9}$ This decrease is inferior to the ones found by Hanni, Martner and Podestá (2015) in the more developed South American countries such as Chile, Argentina, Mexico and Uruguay, where it varies from 2.9 per cent to 4.8 per cent, and far inferior to the OECD average, which would be around 6 per cent according to Joumard, Pisu and Bloch (2012).

It is evident that the more developed countries have higher average incomes and less inequality, guaranteeing broader bases for taxation. In the case of the Brazilian middle income and high inequality economy the PIT ends up being constrained to a tiny portion of the population - almost restricted to the richest 10 per cent - thus limiting its redistributive power, even though the role of tax benefits conferred to capital incomes should not be overlooked. This slight progressivity result must also be relativised due to the inflexion of average rates at the top of the distribution, which violates the principle of progressivity. Rates increase until their apex of 12.3 per cent, for the first half of the richest 1 per cent of the population, and drop to 7 per cent for the top 0.05 per cent.

A last notable aspect of these results is that they reveal substantially higher levels of top income concentration, compared to usual analyses based on household surveys, corroborating the results from the study by Medeiros, Souza and Castro (2015). Our results based on more recent tax data are similar: the richest 10 per cent concentrates a little more than half of the total income (50.8 per cent), the top 1 per cent close to one fifth (21.9 per cent), and the top 0.1 per cent reaches one tenth (10.2 per cent). This study's additional contribution is to show that the concentration is even more impressive when one reaches the top 0.05 per cent: around 71,000 people hold 8.2 per cent of all income. This is unparalleled, as can be concluded by comparing Brazil with other countries with available data (see Figure 1).

\footnotetext{
${ }^{8}$ See the supplementary appendix for methodological details, available with the full digital version of this article.

${ }^{9}$ The Gini value is lower than the 0.688 from Medeiros and Souza (2014), who also investigate inequality combining tax data with microdata from household surveys, probably because they did not applied any procedure to correct incomes at the bottom of the distribution. The decrease in the Gini index of 2.3 per cent, on the other hand, is close to microsimulations results with household surveys of 2.0 per cent in Soares et al. (2010) and 2.3 per cent in Hanni, Martner and Podestá (2015).
} 
Although international comparisons must be approached with caution, as the measurements and concepts for population and income might differ between countries.

Table 6: Distribution of income and average PIT rates in 2013

\begin{tabular}{|c|c|c|c|c|c|c|c|c|c|}
\hline \multirow{2}{*}{$\begin{array}{c}\text { Cumulative portion of } \\
\text { population }\end{array}$} & \multicolumn{3}{|c|}{$\begin{array}{l}\text { Participation in total } \\
\text { pre-PIT income }\end{array}$} & \multicolumn{3}{|c|}{$\begin{array}{l}\text { Participation in total } \\
\text { post-PIT income }\end{array}$} & \multicolumn{3}{|c|}{ Average tax rate } \\
\hline & Labour & Capital & Total & Labour & Capital & Total & Labour & Capital & Tota \\
\hline Up to $10 \%$ & 0.0 & 0.0 & 0.0 & 0.0 & 0.0 & 0.0 & 0.0 & 0.0 & 0.0 \\
\hline From $10 \%$ to $20 \%$ & 0.0 & 0.0 & 0.0 & 0.0 & 0.0 & 0.0 & 0.0 & 0.0 & 0.0 \\
\hline From $20 \%$ to $30 \%$ & 1.8 & 0.0 & 1.8 & 1.9 & 0.0 & 1.9 & 0.0 & 0.0 & 0.0 \\
\hline From $30 \%$ to $40 \%$ & 4.4 & 0.0 & 4.4 & 4.6 & 0.0 & 4.6 & 0.0 & 0.0 & 0.0 \\
\hline From $40 \%$ to $50 \%$ & 4.6 & 0.0 & 4.6 & 4.8 & 0.0 & 4.8 & 0.0 & 0.0 & 0.0 \\
\hline From $50 \%$ to $60 \%$ & 5.6 & 0.0 & 5.7 & 5.9 & 0.0 & 5.9 & 0.0 & 0.0 & 0.0 \\
\hline From $60 \%$ to $70 \%$ & 7.1 & 0.1 & 7.3 & 7.4 & 0.1 & 7.6 & 0.0 & 0.0 & 0.0 \\
\hline From $70 \%$ to $80 \%$ & 9.2 & 0.2 & 9.4 & 9.6 & 0.2 & 9.8 & 0.0 & 0.0 & 0.0 \\
\hline From $80 \%$ to $90 \%$ & 13.1 & 0.8 & 13.9 & 13.6 & 0.8 & 14.4 & 0.2 & 1.0 & 0.3 \\
\hline From $90 \%$ to $95 \%$ & 9.8 & 1.2 & 11.0 & 9.9 & 1.2 & 11.2 & 3.0 & 3.2 & 3.0 \\
\hline From $95 \%$ to $96 \%$ & 2.7 & 0.4 & 3.1 & 2.7 & 0.4 & 3.1 & 3.8 & 3.3 & 3.8 \\
\hline From $96 \%$ to $97 \%$ & 3.1 & 0.7 & 3.8 & 2.9 & 0.7 & 3.6 & 10.2 & 3.3 & 8.9 \\
\hline From $97 \%$ to $98 \%$ & 4.0 & 0.8 & 4.7 & 3.7 & 0.8 & 4.5 & 10.2 & 3.3 & 9.1 \\
\hline From $98 \%$ to $99 \%$ & 5.4 & 1.6 & 7.0 & 4.9 & 1.7 & 6.5 & 13.4 & 3.1 & 11.0 \\
\hline From $99 \%$ to $99.5 \%$ & 3.9 & 1.3 & 5.1 & 3.4 & 1.3 & 4.7 & 15.3 & 3.0 & 12.3 \\
\hline From $99.5 \%$ to $99.9 \%$ & 4.5 & 3.1 & 7.6 & 3.9 & 3.1 & 7.1 & 16.8 & 2.8 & 11.1 \\
\hline From $99.9 \%$ to $99.95 \%$ & 0.7 & 1.3 & 2.0 & 0.6 & 1.3 & 1.9 & 16.3 & 2.7 & 7.7 \\
\hline From $99.95 \%$ to $100 \%$ & 2.3 & 6.2 & 8.5 & 2.0 & 6.2 & 8.2 & 14.8 & 4.1 & 7.0 \\
\hline Total & 82.2 & 17.8 & 100.0 & 82.1 & 17.9 & 100.0 & 4.5 & 3.2 & 4.3 \\
\hline Gini index & - & - & 0.6466 & - & - & 0.6319 & - & - & - \\
\hline
\end{tabular}

Source: Authors' elaboration based on DIRPF, National Household Sample Survey (PNAD) and national accounts.

Figure 1: Participation of the richest 1 per cent in total income

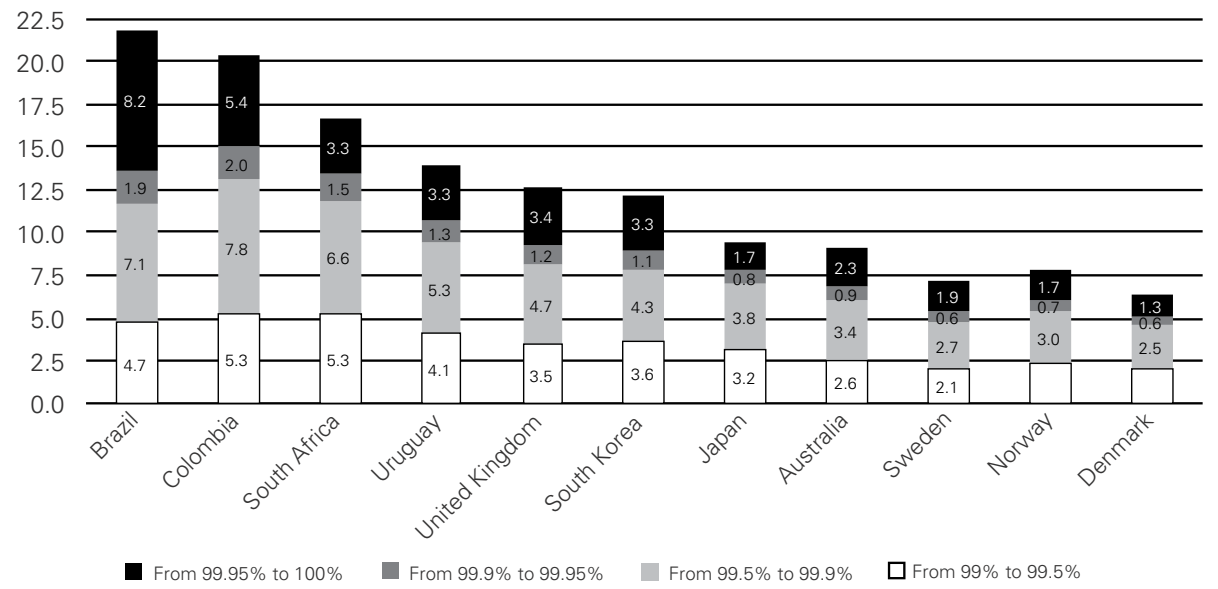

Source: Authors' elaboration based on own calculations for Brazil and data from The World Top Incomes Database (extracted 19 September 2015).

Note: Sample relative to countries with available data for income concentration at the 0.05 per cent richest. 


\section{SIMULATION OF CHANGES IN PIT LEGISLATION}

The structure of PIT in Brazil is not very progressive as a whole, when one considers the different types of income and tax treatments. The fact that a predominant portion of the income of the richest comes from capital ownership and will be tax-free or subject to linear rates that are lower than the ones applicable to labour income creates countless distortions, such as the effective tax rate for the richest being lower than for the middle strata of taxpayers, as seen in the previous section. Therefore, measures targeting the increase of tax progressivity are recommended not to depend solely, or primarily, on the structure of rates applied to wages and other taxable income. It is necessary to expand the taxable base by including incomes that are currently tax-free, such as dividends.

To ground this proposition, we present, as follows, a series of simulations regarding alternative proposals for changes in tax legislation. Three effects are estimated: over revenue, inequality (represented by change in the Gini index) and the number of people affected. These are static simulations that do not consider possible dynamic effects but nevertheless contribute to the comparative analysis of the different tax alternatives.

The present PIT structure generated BRL149.7 billion in revenue in 2013 and reduced inequality, as measured by the Gini index, by 2.3 per cent. Considering this reference scenario, four others were simulated to capture the effect of different alterations in tax legislation: ${ }^{10}$

1. The first alternative, of taxing dividends as in up to 1995 , with a 15 per cent withholding tax, independently of the recipient's total income, would reach 2.1 million people, increase revenue by BRL43 billion (2013 values) and reduce inequality by 2.9 per cent.

2. The second alternative, of taxing dividends according to the current progressive table, with an exemption bracket and rates varying from 7.5 per cent to 27.5 per cent, would yield an additional BRL66.4 billion in revenue, reaching 1.3 million people and reducing inequality by 3.4 per cent.

3. The third alternative, of maintaining dividend exemption but changing the progressive tax table, would have to be profound enough to raise the current top income tax to 30 per cent and create of three new rates ( 35 per cent, 40 per cent and 45 per cent) from modest income levels (BRL61,495, BRL71,731 and BRL81,967, respectively) to obtain a similar income inequality reduction as the first alternative, less additional revenue and reach a far larger number of taxpayers (4.6 million).

4. The fourth and last alternative under analysis is to create an additional rate of 35 per cent exclusively for very high incomes (over BRL325,000) and simul-

\footnotetext{
${ }^{10}$ See the supplementary appendix for methodological details, available with the full digital version of this article.
} 
taneously to submit profits and dividends to the progressive table, as in the second alternative. This would reach around 1.5 million people, generate an additional BRL78.2 billion in revenue and reduce inequality by 3.6 per cent.

Table 7: Simulation of potential effects of different changes in PIT, based on 2013

\begin{tabular}{|c|c|c|c|c|c|}
\hline \multirow{2}{*}{ Tax alternatives } & \multirow{2}{*}{$\begin{array}{l}\text { Revenue } \\
\text { (BRL } \\
\text { billion) }\end{array}$} & \multirow{2}{*}{$\begin{array}{l}\text { Affected } \\
\text { taxpayers } \\
\text { (millions) }\end{array}$} & \multicolumn{3}{|c|}{ Gini index } \\
\hline & & & Pre-PIT & Post-PIT & rowth Rate \\
\hline Current PIT structure & 149.7 & - & 0.6466 & 0.6319 & $-2.3 \%$ \\
\hline $\begin{array}{l}\text { 1. Reinstitution of dividends taxation by the } 15 \text { per cent } \\
\text { linear rate }\end{array}$ & 192.83 & 2.101 & 0.6466 & 0.6276 & $-2.9 \%$ \\
\hline 2. Taxation of dividends by progressive rates $(0-27.5 \%)$ & 216.16 & 1.342 & 0.6466 & 0.6249 & $-3.4 \%$ \\
\hline $\begin{array}{l}\text { 3. Raise of the top rate }(30 \%) \text { and creation of three additional } \\
\text { rates ( } 35 \%, 40 \% \text { and } 45 \%) \text {, maintaining the exemption of } \\
\text { dividends }\end{array}$ & 190.12 & 4.616 & 0.6466 & 0.6271 & $-3.0 \%$ \\
\hline $\begin{array}{l}\text { 4. Inclusion of an additional rate and taxation of dividends by } \\
\text { progressive rates }(0-35 \%)\end{array}$ & 227.89 & 1.472 & 0.6466 & 0.6236 & $-3.6 \%$ \\
\hline
\end{tabular}

Source: Authors' elaboration.

Analysing the magnitude of variations in inequality indicators, the effects might not seem very significant, which is explained by the fact that the simulations impact a small proportion of the population at the top of the distribution, and that the Gini index is more sensitive to changes in the middle of the income distribution, which in the Brazilian case comprises dozens of millions of people with low income that are exempt from PIT. In any case, simulations suggest that taxation of dividends would bring the distributive effect of PIT in Brazil closer to the levels seen in Mexico and Uruguay (4.8 per cent and 4.0 per cent, respectively).

In turn, the alternative to increase progressivity by creating additional rates while still maintaining the exemption of dividends requires reaching a much larger number of taxpayers to yield a similar level of reduction in the Gini index and a lower revenue compared with the alternative of taxing dividends by a linear 15 per cent rate - in addition to obscuring a relevant fact, which is the increase in inequality between the intermediary and the top strata of taxpayers. This occurs because, proportionally to their income, the intermediary strata - especially salaried workers - would be more burdened than the very rich, keeping in mind that a significant part of the latter's income would remain exempt.

These results indicate that the PIT would become more progressive if dividends were to be taxed. Alternatives limited to tweaking the tax table without broadening the taxable base might yield some redistributive effect but will be more closely linked to income transfer from upper-middle-class salaried workers than from capital owners.

\section{CLOSING REMARKS}

This study has undertaken a historic analysis of income tax in Brazil, showing how the tax measures that reduced its progressivity between the 1980s and 1990s 
and benefited capital owners were influenced by theoretical concepts that are being questioned and revised even in mainstream economic theory, whose main expression are the works of Piketty (2014). It is noteworthy that this inflexion in Brazilian taxation policy, abandoning redistributive goals, has occurred simultaneously to recognising a series of social rights and benefits inscribed in the 1988 Constitution. In developed countries, the progressivity of the tax system have been at the core of the construction of their welfare states.

This seeming paradox is the result of one of the main economic policy prescriptions that mainstream economics disseminated in the 1980s and 1990s, according to which the redistributive function of fiscal policy should be exercised only via expenditures, falling on the tax authority to collect levies with a minimal level of economic distortion. It is clear that the Brazilian tax system has not advanced significantly towards greater economic efficiency as foreseen by like-minded normative theorists but, rather, has been used very creatively to ensure tax benefits to capital owners, such as through the deductibility of JSCP and tax-free dividends.

As observed, Brazil is one of the few countries in the world where such mechanisms are enforced. It was also shown that taxation of profits and dividends, considering the load on both corporate and personal levels, is higher as an average in OECD countries than in Brazil, despite similar overall tax burdens.

In addition, based on analysis of tax data recently made available by the Federal Revenue, the following conclusions were reached:

- The level of top income concentration in Brazil is significantly higher than has been estimated based on the usual household surveys, confirming the results seen in Medeiros, Souza and Castro (2015). Around half of the total income is concentrated among the richest 10 per cent, a little above a fifth among the top 1 per cent, and close to one tenth among the top 0.1 per cent, far surpassing the tolerable limits for democratic societies, according to Piketty (2014). Our additional contribution is to show that the concentration is even more impressive in the top 0.05 per cent, which appropriates 8.2 per cent of all income. Such distribution is unparalleled worldwide, at least according to data currently available in The World Top Incomes Database.

- PIT structure is not very progressive and favours such a concentration. The redistributive effect of the PIT, measured as a decrease in the Gini index of 2.3 per cent, is lower than in other Latin American countries such as Chile, Argentina, Mexico and Uruguay, and considerably lower than the OECD average. Even this result that points towards the slight progressivity of the PIT must be relativised, because the principles of horizontal and vertical equity are violated (and, therefore, the concept of progressivity itself). The average effective rate, considering total income, increases progressively until the beginning of the last hundredth of the distribution, reaching 12.3 per cent, but then falls to 7 per cent among the 0.05 per cent richest. On average, the 0.05 richest pay less taxes, proportionally to their income, than 
around 5.8 million people, including parts of the upper-middle-class, with yearly incomes above BRL81,4 thousands.

In short, tax benefits to capital income, among other asymmetries, contribute to the fact that Brazil has one of the highest - if not the highest - top income concentrations worldwide. This situation could be partially reversed by the reinstitution of the taxation over dividends. Were they taxed according to the current progressive tax table, simulations show that the redistributive effect, as measured by the decrease in the Gini index, would grow to around 3.6 per cent, approximating the rates of Uruguay and Mexico but still quite far from the average of OECD countries.

However, the same simulations suggest that the simple creation of additional tax rates and not taxing dividends would not yield the same revenue increase, or the same redistributive effects, even if a much larger number of taxpayers were reached, up to intermediary strata with taxable income superior to BRL51.259 and with marginal rates of up to 45 per cent. In this case, the income disparities would increase between the upper-middle-class - especially salaried workers - and the very rich, the majority of whose income would remain exempt.

Facing this situation, it is suggested that measures geared towards progressivity, in order not to make distortions worse, be oriented mainly to increasing the tax base, including currently tax-free incomes such as dividends. This is also a feasible path for the government to increase its revenue, given the current scenario of fiscal adjustments, by concentrating the burden at the top of the distribution.

In addition, it is argued that the viability of the approval of such measures in the current troublesome political scenario would be improved if they were part of a broader tax reform that, in tandem with taxing dividends, also reduces CIT, aligning Brazil's tax system with common practices of OECD countries.

Furthermore, as part of these measures, it is suggested that the fiscal space created by the taxation of dividends, which in the short term would contribute to fiscal adjustment efforts, be channelled towards a medium-term reform of the main indirect federal tax (PIS/Cofins), based both on its transformation into a unified value added tax as well as the incremental reduction of its rates. In that sense, at the end of a transition period, the overall tax burden could return to initial levels.

A reform with these characteristics has the considerable advantage of combining equity with efficiency, which tends to favour the performance of the Brazilian economy. Gains, in terms of progressivity, are clear because they both broaden the redistributive impact of the PIT and reduce taxation on goods and services, which has a regressive profile. From the perspective of economic efficiency, gains are a result of tax standardisation and simplification; a change in the composition of income tax with the reduction of rates at the corporate level; and an increase in local production competitiveness by the reduction of value added tax.

Even among neoclassical economists who are against the progressivity of taxes, few would dispute the net efficiency gains of a tax reform on these lines. On the other hand, among Keynesian economists there would be more unanimous support, because it implies focusing taxes on a small portion of the savings of very wealthy 
families, not directly related to investment and, therefore, attached to a higher level of employment and production. ${ }^{11}$

In short, such a proposition illustrates a possible path for tax reform, with characteristics that favour inclusive growth and more likely to accrue support from society and be approved in Congress. The most important step is to make use of the space that is being opened - from the repercussions of the international debate around taxation and inequality, to Piketty's works (2014), and the recent availability of greater detail around Brazilian tax data - to recover the long since neglected progressive agenda in the country.

\section{REFERENCES}

Afonso, J.R. 2014. “IRPF e desigualdade em debate no Brasil: o já revelado e o por revelar.” Texto para Discussão, No. 42. Rio de Janeiro: FGV-Ibre.

Altshuler, Rosanne, Benjamin H. Harris, and Eric Toder. 2010. "Capital income taxation and progressivity in a global economy." Va. Tax Rev. 30: 355.

Atkinson, A., and J.E. Stiglitz. 1976. "The Design of Tax Structure: Direct Versus Indirect Taxation.” Journal of Public Economics, 6(1-2): 55-75.

Banks, J., and P. Diamond. 2010. “The Base for Direct Taxation.” In Dimensions of Tax Design: The Mirlees Review, edited by The Institute for Fiscal Studies (IFS), Chapter 6: 548-648. Oxford: Oxford University Press.

Castro, F. 2014. "Imposto de Renda da Pessoa Física: comparações internacionais, medidas de progressividade e redistribuição.” Master’s dissertation. Brasília: Universidade de Brasília.

Diamond, P., and E. Saez. 2011. "The Case for a Progressive Tax: From Basic Research to Policy Recomendations." Journal of Economic Perspectives, 25(4): 165-190.

Freitas, E.E., N.E.S. Costa, and A.G. Moreira. 2012. “Tributação da distribuição de lucros.” Presented at the Congresso Nacional dos Auditores Fiscais.

$<$ http://www.conaf2012.org.br/index.php?option=com_phocadownload\&view=category\&download= 26:tributacao-da-distribuicao-de-lucros\&id=3:justica-fiscal\&Itemid=498>. Accessed 2 December 2015.

Gobetti, S.W., and R. Orair. 2015. "Distribuição e tributação da renda no Brasil: novas evidências a partir das declarações fiscais das pessoas físicas.” ANPEC: Anais do XXXXIII Encontro Nacional.

Hanni, R., M. Martner, and A. Podestá. 2015. “El potencial redistributivo de la fiscalidad en América Latina.” Revista Cepal, 116, August.

Hoffmann, R. 2002. “O efeito potencial do imposto de renda na desigualdade.” Pesquisa e Planejamento Econômico, Vol. 32, No. 1, April.

Johansson, A., C. Heady, J. Arnold, B. Brys, and L. Vartia. 2008. "Taxation and economic growth." Working Paper, No. 620. Paris: Economics Department, Organisation for Economic Co-operation and Development.

Joumard, I., M. Pisu, and D. Bloch. 2012. "Less income inequality and more growth - Are they compatible?" In: Income redistribution via taxes and transfers across OECD countries. Working Paper,

\footnotetext{
${ }^{11}$ It is worth mentioning not only theoretical studies following general equilibrium models such as Altshuler et al. (2010), but especially a broad empirical literature synthesised in Johansson et al. (2008), which posit that CIT has more damaging effects on growth than the PIT. About the Keynesian perspective, see Mott and Slattery (1994).
} 
No. 926. Paris: Economics Department, Organisation for Economic Co-operation and Development.

Medeiros, M., and P.H. Souza. 2014. "A estabilidade da desigualdade no Brasil, 2006 e 2012: estimativas com dados do imposto de renda e pesquisas domiciliares." Ciência Saúde Coletiva.

Medeiros, M., P.H. Souza, and F.A. Castro. 2015. "O Topo da Distribuição de Renda no Brasil: primeiras estimativas com dados tributários e comparação com pesquisas domiciliares (2006-2012).” DADOS - Revista de Ciências Sociais, Vol. 58, No. 1: 7-36.

Mirrlees, J.A. 1971. “An Exploration in the Theory of Optimal Income Taxation.” Review of Economic Studies, 38: 175-208.

Mott, T., and E. Slattery. 1994. "Tax incidence and macroeconomic effects in a Kaleckian model when profits finance affects investment and prices may respond to taxes." Journal of Post Keynesian Economics, Vol. 16, No. 3, Spring.

Piketty, T. 2014. Capital in the XXI century. Cambridge, MA: Harvard University Press.

Piketty, T., E. Saez, and G. Zucman. 2013. Rethinking capital and wealth taxation. Mimeo.

Rocha, S. 2002. "O impacto distributivo do imposto de renda sobre a desigualdade de renda das famílias.” Pesquisa e Planejamento Econômico, Vol. 32, No. 1, April.

Secretaria da Receita Federal do Brasil (SRFB). 2004. "O Imposto de Renda das Pessoas Físicas no Brasil.” Estudos Tributários, No. 14, December.

Secretaria da Receita Federal do Brasil (SRFB). 2015. "Grandes Números das Declarações de Imposto de Renda das Pessoas Físicas.” (Various years). <http://idg.receita.fazenda.gov.br/dados/receitadata/estudos-e-tributarios-e-aduaneiros/estudos-e-estatisticas/11-08-2014-grandes-numeros-dirpf/ grandes-numeros-dirpf-capa>. Accessed 2 December 2015.

Silveira, F.G. 2008. "Tributação, previdência e assistência sociais: impactos distributivos.” Doctoral thesis. Campinas: Universidade Estadual de Campinas (UNICAMP).

Soares, S., F.G. Silveira, C.H. Santos, F.M. Vaz, and A.L. Souza. 2010. "O Potencial Distributivo do Imposto de Renda-Pessoa Física (IRPF).” In Tributação e equidade no Brasil: um registro da reflexão do Ipea no biênio 2008-2009, edited by J.A. Castro, C.H. Santos, and J.A. Ribeiro. Brasília: Ipea. 